\title{
$\square$
}

\section{International Trade, Female Labor, and Entrepreneurship in MENA Countries}

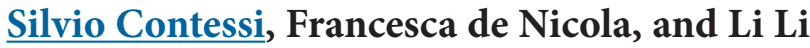

\begin{abstract}
Middle Eastern and North African (MENA) countries stand out in international comparisons of de jure obstacles to female employment and entrepreneurship. These obstacles manifest themselves in low rates of female labor participation, entrepreneurship, and ownership. Recent research suggests a connection between international trade and female labor participation. In this article, the authors focus on the relationship between international trade and gender in the MENA countries. They first analyze female labor as a production factor and then focus on female entrepreneurship and firm ownership. The authors use country- and industry-level data to identify countries and industries characterized by a comparative advantage in female labor. They find evidence suggesting a strong link between a country's specialization and its measures of female labor participation consistent with theories of brain-based technological bias and factor endowments trade theories. Using firm-level data, the authors then study whether trade empowers female entrepreneurs in country/industry pairs that exhibit comparative advantage. They conclude that the evidence supports the view that exposure to trade disproportionately affects firms in country/industry pairs with a comparative advantage in female labor-both in terms of female employment and female entrepreneurship and ownership-for the MENA countries and the period they study. (JEL F11, F14, F16, J82)
\end{abstract}

Federal Reserve Bank of St. Louis Review, January/February 2013, 95(1), pp. 89-114.

$\mathbf{T}$ he relationship between trade and gender has recently emerged as an important theme in the international economics and development literature. The United Nations' Millennium Development Goal No. 3 is to promote gender equality and empower women, a broad goal that can cover many areas of economic and non-economic activity. The entire World Development Report 2012: Gender Equality and Development (WDR; World Bank, 2011 ) is devoted to the study of gender issues, and its chapter 5 focuses specifically on the relationship between trade and gender, highlighting the main conceptual issues and presenting several interesting research avenues. In fact, this explicit effort is reinforcing research on gender at both the macroeconomic and microeconomic levels.

Silvio Contessi is an economist and Li Li is a research associate at the Federal Reserve Bank of St. Louis. Francesca de Nicola is a postdoctoral fellow at the International Food Policy Research Institute. The authors are grateful to Ali Bayar, Subhayu Bandyopadhyay, Maria Canon, Elisa Keller, Marcella Nicolini, Jeff Nugent, and participants to the MEDalics workshop on "Multinational Strategies, Economic Integration, and Knowledge Transfer in the Mediterranean Area" for constructive comments.

(c) 2013, The Federal Reserve Bank of St. Louis. The views expressed in this article are those of the author(s) and do not necessarily reflect the views of the Federal Reserve System, the Board of Governors, or the regional Federal Reserve Banks. Articles may be reprinted, reproduced, published, distributed, displayed, and transmitted in their entirety if copyright notice, author name(s), and full citation are included. Abstracts, synopses, and other derivative works may be made only with prior written permission of the Federal Reserve Bank of St. Louis. 


\section{Contessi, de Nicola, Li}

Macroeconomic evidence suggests that female labor participation decisions have important aggregate consequences and are correlated with certain forms of technological change that may affect women differently than men; specifically, although women are on par with men in "brainintensive" skills and abilities, women tend to have a comparative disadvantage in "brawnintensive" activity. When technological change favors brain-intensive activities, women can exploit their comparative advantage in these occupations. Microeconomic evidence affords a better understanding of some of the mechanisms that "empower" women-for example, within the household in both advanced economies and in a developmental context. In this article, we attempt to analyze the relationship between international trade and gender-defined here as both female labor participation and female ownership and entrepreneurship-in the Middle Eastern and North African (MENA) countries. This region is interesting in a cross-country perspective because international comparisons of de jure indicators suggest that MENA countries are characterized by more marked gender discrimination in female labor participation and entrepreneurial activity than most other regions of the world.

To this end, we adopt a factor-endowment perspective and construct measures of female labor use (or intensity) at the country/industry pair level and match them to manufacturing trade data to determine the female labor content of exports. Next, we identify country/industry pairs characterized by comparative advantage in female labor for five countries for which aggregated data are available. We then compare our classification of country/industry pairs based on comparative advantage in aggregated data with a similar classification based on firm-level data from the World Bank Enterprise Surveys (WBESs). We find that the two datasets track each other quite well, which allows us (and potentially other researchers using the same procedure) to exploit the firm-level data for other MENA countries for which aggregated data are not available.

Finally, we study whether exposure to trade in comparative advantage country/industry pairs empowers women by increasing the probability of female entrepreneurship and ownership in firms belonging to country/industry pairs with comparative advantage. We find some support for the (theory-free) hypothesis that comparative advantage empowers female entrepreneurs in country/industry pairs with comparative advantage.

The article is organized as follows. The next section provides an overview of female labor market and entrepreneurship in MENA countries. We then discuss the relevant literature and describe the data used in the empirical analysis detailed in the following sections.

\section{AN OVERVIEW OF FEMALE LABOR MARKETS AND ENTREPRENEUR- SHIP IN MENA COUNTRIES}

In addition to anecdotal evidence of gender bias, MENA countries stand out in international comparisons of de jure indicators as being characterized by more marked gender discrimination in female labor participation and entrepreneurial activity than other countries. This position is clearly represented in Figure 1, which shows a summary measure of female discrimination by groups of countries based on the World Bank's 2010 Women, Business and the Law (WBL) dataset. 1

The WBL is a cross-country dataset reporting information on differential legal treatment experienced by women with regard to business-related activities. We use this information and 


\section{Figure 1}

\section{De Jure Differentiations (by Country Group and Country)}
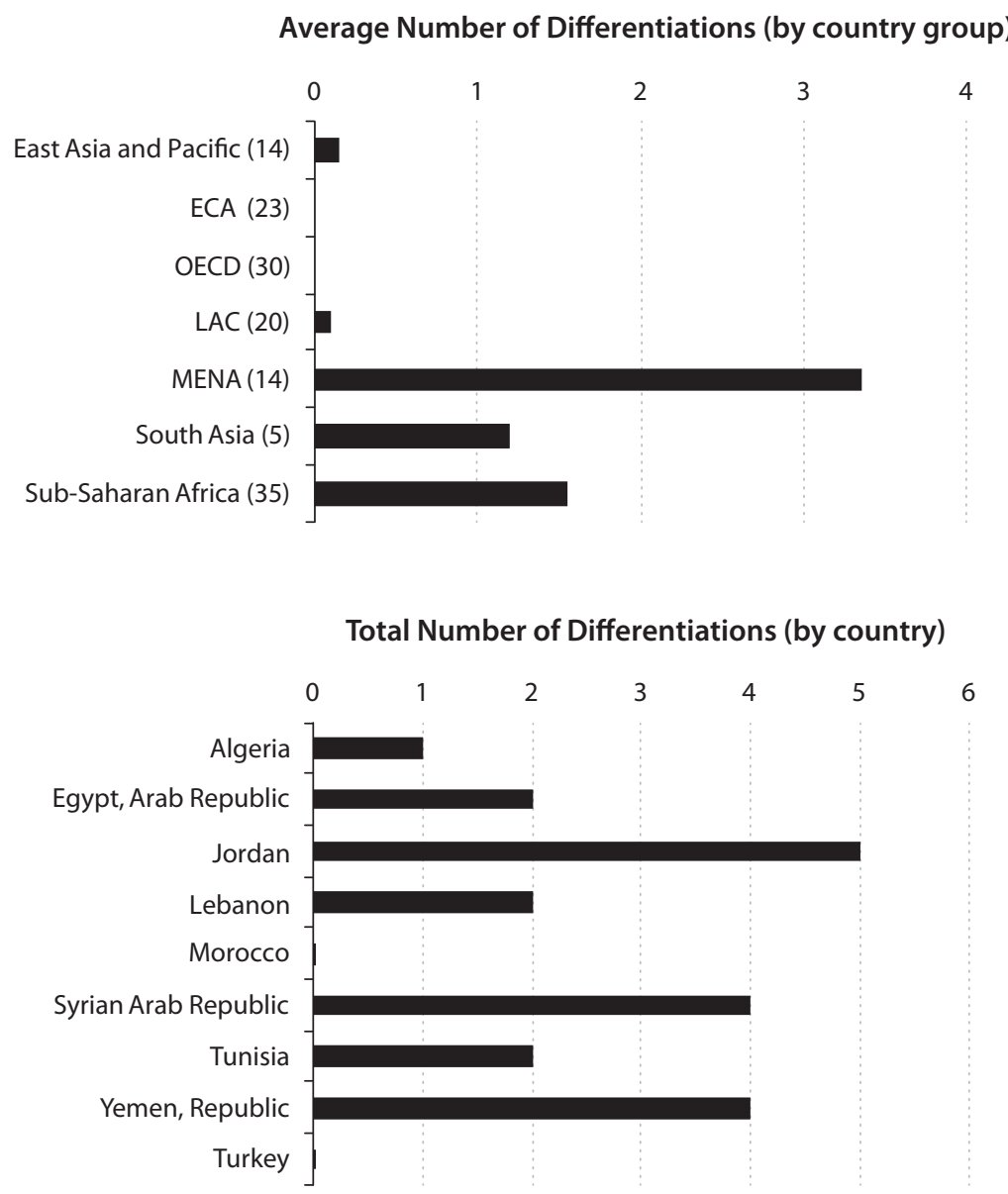

NOTE: In the top panel the number of countries in each region is listed in parentheses. LAC, Latin America and Caribbean; OECD, Organisation for Economic Co-operation and Development.

SOURCE: 2010 Women, Business and the Law dataset of the World Bank. The MENA countries are Algeria, Arab Republic of Egypt, Islamic Jordan, Kuwait, Lebanon, Morocco, Oman, Saudi Arabia, Syrian Arab Republic, Tunisia, United Arab Emirates, West Bank, Gaza, and Yemen.

plot the number of differential treatments by both aggregate geographic regions and individual countries. The top panel of Figure 1 reports the statistics by geographic regions; the number of countries in each region is listed in parentheses. In particular, the top graph is constructed using a subset of questions specifically focused on entrepreneurship and business. 2 Each question in the WBL dataset highlights whether women in business face restrictions in a specific activity (for example, starting a business) relative to men. For each group of countries, each bar in the graphs represents the average count of differential treatment instances. Similar to sub-Saharan Africa, the MENA countries clearly stand out for the high number of reported de jure discrimination episodes against women. The bottom panel focuses on only the MENA region and indicates that gender discrimination is particularly severe in Jordan, Syria, and Yemen. 
Contessi, de Nicola, Li

Figure 2

Labor Participation Rate in 2010 (by Gender)

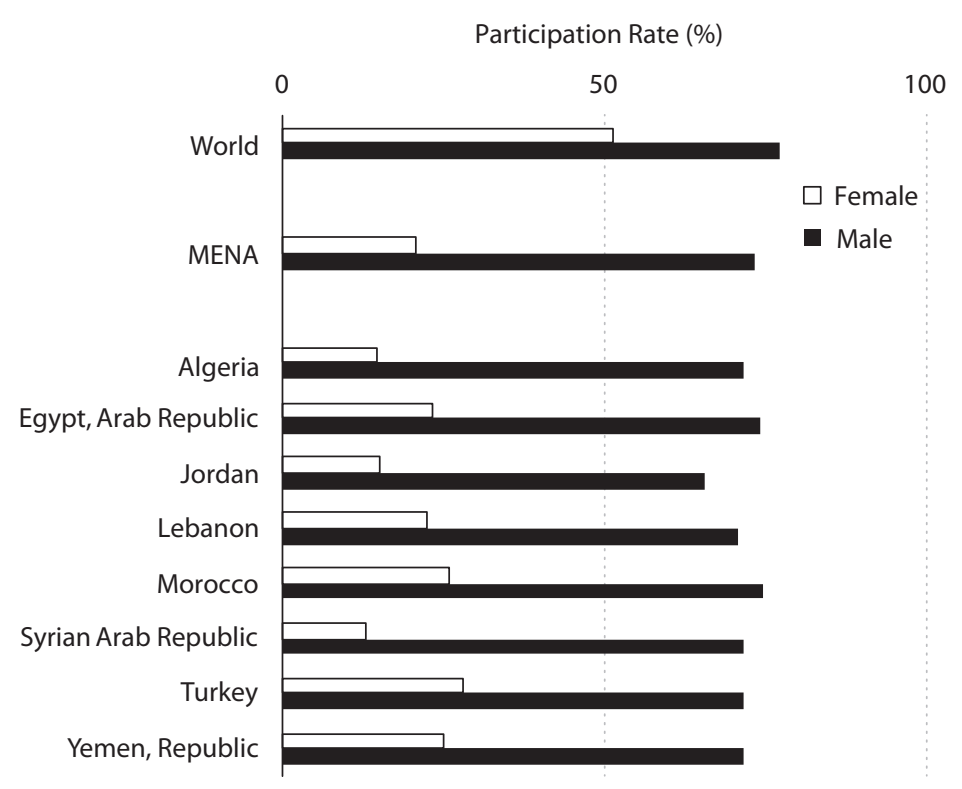

NOTE: The participation rate is the percentage of the working male and female population 15 years of age or older in 2010. SOURCE: World Development Indicators 2011.

The graphs underscore the importance of de jure discrimination in the MENA region and suggest that female labor participation and entrepreneurship may be negatively affected but do not address whether de jure obstacles translate directly into de facto discrimination and whether this is then reflected in women's labor and/or entrepreneurship decisions. Figure 2 uses data from the World Bank's World Development Indicators for 2011 to plot male and female labor participation for the world and the MENA region at both regional and country levels. The figure shows that while male labor force participation in the MENA countries is aligned with the world level, female labor force participation is substantially lower. There is some heterogeneity within the MENA group: Turkey and-to a lesser extent-Morocco stand out for the high incidence of female workers in the economy. Even within the rough picture provided by aggregate data, substantial heterogeneity exists both within the group of countries and within individual countries.

A somewhat comparable neighboring region consists of the 27 transition economies in Eastern Europe and Central Asia (ECA). Figure 3 considers the firm-level dispersion of the use of female labor and plots the frequency of female workers as shares of total workers in surveyed firms in the MENA and ECA regions in firm-level data collected from WBESs, as described in the next section. The histograms clearly indicate a more lopsided distribution of this measure in the MENA countries, with a large mass at 0 to 4 percent. By comparison, firms in the ECA region have a more uniform distribution that is closer to similar plots for advanced economies. Figure 4 further divides this histogram to show individual countries and suggests cross-country heterogeneity in female labor as an input in each country's firms. The distributions in Morocco and 


\section{Figure 3}

Frequency of Female Workers as a Share of Total Workers in Surveyed Firms in the MENA Region and in the BEEPS

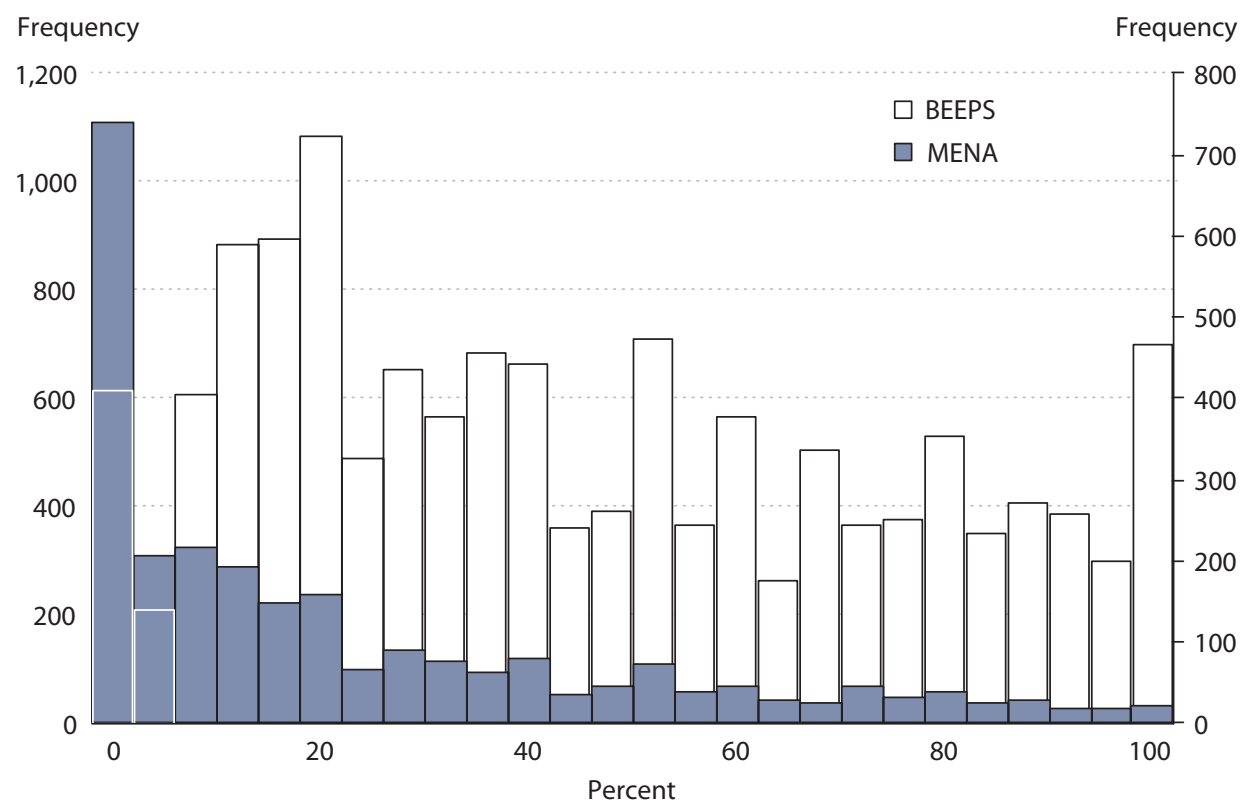

NOTE: BEEPS, Business Environment and Enterprise Performance Survey. ECA data refer to the 2007 fiscal year; MENA data refer to countries' fiscal years as specified in Table 2.

SOURCE: World Bank Enterprise Surveys and Business and Enterprise Performance Survey.

Turkey are closer to those in the ECA region, while the histograms for other countries show approximately a negative exponential distribution, which is extremely lopsided in the case of Yemen.

Finally, Figure 5 uses the same data source to consider de facto indicators of female entrepreneurship participation, particularly the incidence of female ownership and female management. While Lebanon and Turkey show measures of the incidence of female owners that are comparable to the world in general, Algeria, Jordan, Morocco, Syria, and Yemen contribute to the low incidence of female owners in the MENA region overall. In contrast, the incidence of female managers in top management is higher than in the rest of the world for most countries in the MENA group for which data are available — that is, Egypt, Lebanon, and Syria-but extremely low in Yemen.

\section{RELATED LITERATURE}

This article contributes to an emerging literature that highlights the role of gender differences in microeconomic data and macroeconomic models. In quantitative macroeconomic and labor economics, the availability of data on the composition of occupations has generated a small segment of the literature centered on the concept of "brain-based technological change." Male and female labor are not perfect substitutes because individuals are endowed with similar 


\section{Figure 4}

\section{Density of Female Workers as a Share of Total Workers in Surveyed Firms (by MENA Country)}
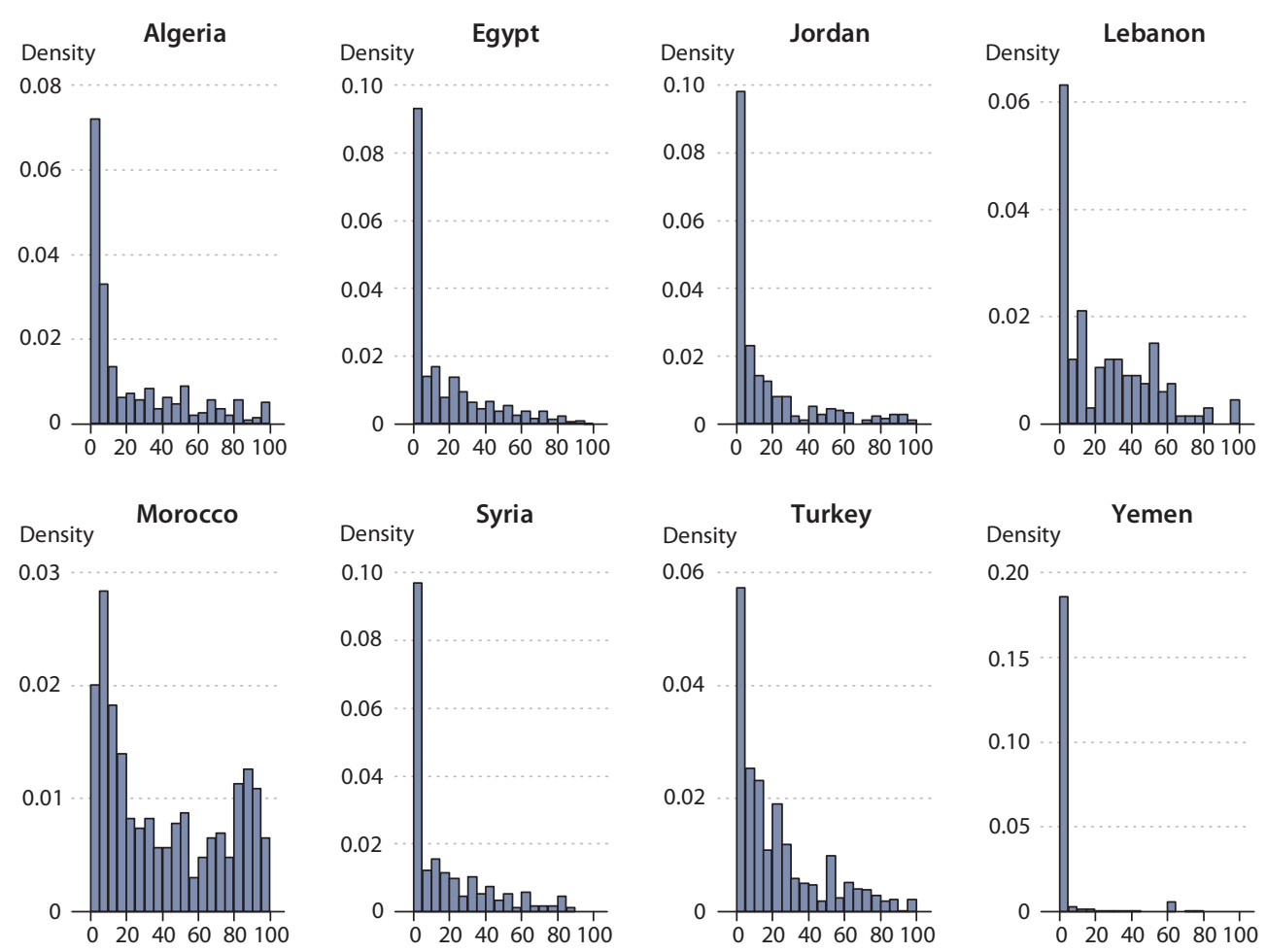

NOTE: MENA data refer to countries' fiscal years as specified in Table 2. SOURCE: World Bank Enterprise Surveys.

brain abilities (mental labor) but different brawn abilities (physical labor) that favor men (Galor and Weil, 1996). As long as brawn skills have a positive marginal return, men enjoy a favorable gender wage gap. However, when technological change is biased in favor of brain-intensive activity, women can specialize according to their comparative advantage. The related increase in female labor demand then pushes wages up and contributes to reducing the wage gap with men, as observed in the U.S. data (see Rendall, 2010, and Keller, 2012).

While this theoretical argument holds for the U.S. economy, the evidence from international data is less clear. On the one hand, cross-country comparisons show a consistent picture for richer but not poorer countries (Oostendorp, 2009). In the former, the wage gap tends to decrease with increasing trade and foreign direct investment (FDI) as well as economic development. In the latter, trade and FDI do not appear to reduce the occupational gender wage gap. These findings are consistent with the possibility that brain-based technological change may have a smaller impact in poorer countries.

On the other hand, Aguayo-Tellez, Airola, and Juhn (2010) reach a different conclusion in their study of the impact in Mexico of liberalization measures resulting from the North American Free Trade Agreement. Women's relative wages increased, and both between- and within- 


\section{Figure 5}

\section{Incidence of Female Ownership and Top Management (Within-Country Average, Various Years)}

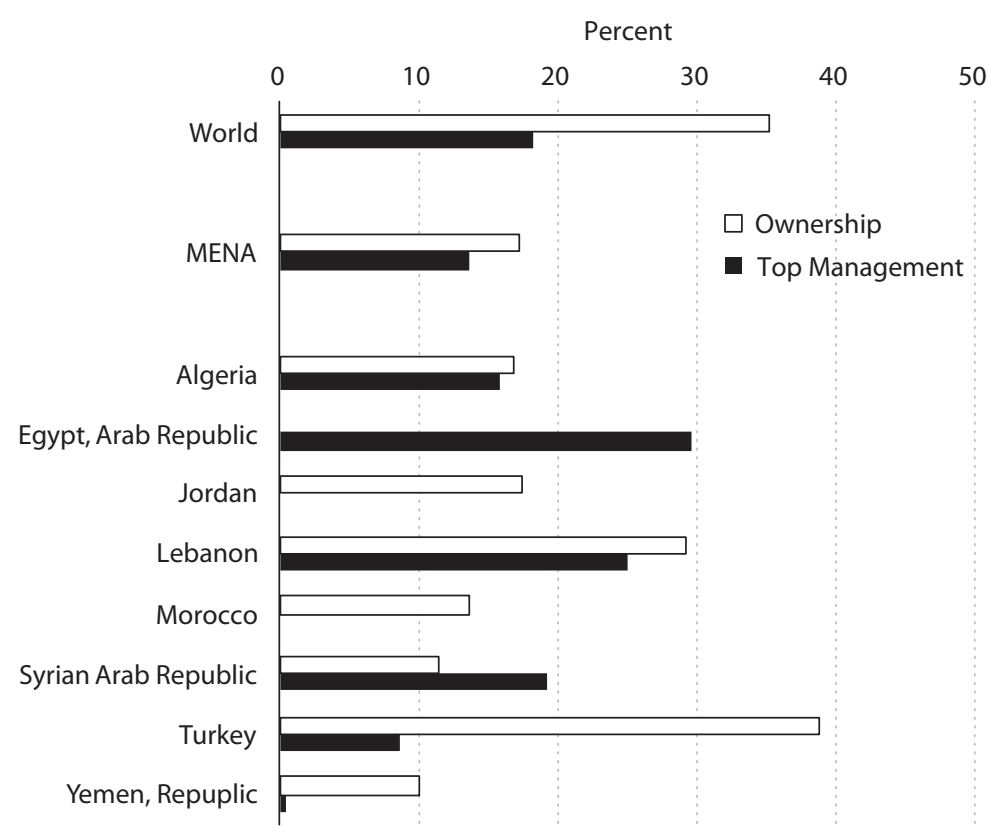

NOTE: "Ownership" is the percent of firms with some female participation in ownership. "Top Management" is the percent of firms with a female top manager.

SOURCE: World Bank Enterprise Surveys, various years.

industry shifts favored female workers since tariff reductions expanded sectors that were initially female intensive. Women also gained intrahousehold bargaining power as documented by the change in expenditure toward goods associated with female preferences (for example, clothing and education).

Do, Levchenko, and Raddatz (2012) offer a different perspective that reconciles these findings. Improvement in trade openness changes the opportunity cost of women staying out of the formal labor market and therefore the trade-off between work and fertility decisions, a point also made by Rees and Riezman (2011). In particular, Do, Levchenko, and Raddatz (2012) develop a specific factor model of trade in which male and female labor are combined with capital in two manufacturing sectors. When trade increases the demand for female labor in country/industry pairs with comparative advantage with intensive use of female labor, trade also induces increases in female labor wages, which in turn affect fertility decisions. Their model is supported by empirical evidence in a large cross section of countries.

Sauré and Zoabi (2009) study similar relationships but focus on the role of capital accumulation on labor by gender. These authors argue that when globalization improves work opportunities for women, female labor participation may drop if international specialization promotes sectors that use female labor intensively. This effect arises because expansions of the former sectors are accompanied by contractions of others that induce male workers to move to the 


\section{Contessi, de Nicola, Li}

expanding sectors, driving female workers out of formal employment. Thus, a country that is exporting female labor content may actually be substituting male labor for female.

Finally, there is a sizable literature on female labor participation and job mobility that includes Gayle, Golan, and Miller (2012); their paper is important for our analysis of entrepreneurship and management because it focuses on job progression and selection, particularly the reasons why fewer women than men become executive managers, earn less over their careers, hold more junior positions, and exit the occupation at a faster rate. The authors find that, controlling for executive rank and background, women earn higher compensation than men, experience more income uncertainty, and are promoted more quickly but also that these differences are related to the difficulties of surviving in the organization. Among survivors, being female increases the chance of becoming CEO because survival is rewarded with promotion and higher compensation.

Because extensive coverage of the literature is beyond the scope of this article, we refer interested readers to the WDR 2012 (World Bank, 2011), which summarizes the debate on the relationship between gender inequality and development. The portions of the report most relevant to our article are chapter 5 (on gender differences in employment) and chapter 6 (on the relationship between globalization and gender inequality). The data in these chapters support the arguments that (i) developing countries are experiencing reductions in male/female wage gaps and (ii) part of these reductions may be related to a country's openness. We contribute to this debate by providing further evidence on the degree of gender labor participation in the MENA region and linking it to international trade.

\section{DATA}

We maintain a flexible definition of the MENA countries because of differences in the availability of data across countries; thus, we combine multiple data sources. The largest group of countries (Algeria, Egypt, Jordan, Lebanon, Morocco, Turkey, Syria, and Yemen) is constrained by the availability of individual WBESs. In addition, we use the United Nations Industrial Development Organization (UNIDO) Industrial Statistics databases (UNIDO INDSTAT2) and the United Nations Commodity Trade Statistics (UN COMTRADE) as data sources. $\frac{3}{}$

The WBESs collect firm-level data from a selected number of countries to provide a representative picture of the population of firms in the countries' economies. Table 1 shows the frequency of firms by country and industry. From the available data we select country/year pairs for the years between 2006 and 2009 to maintain a cross-country perspective as broad as possible (Table 2). Each survey questionnaire is constructed to capture the economic and institutional environment in addition to the main business constraints faced by firms within the country. This information is captured by quantitative and qualitative indicators used in the questionnaire to measure, for example, the level of the firm's sales, the amount of export, FDI intensity, and qualitative perceptions about the business environment. We use all available information regarding the gender dimension of the firm's activity. In addition to standard firm demographic information, the datasets include information on whether any of the firm's owners, top managers, or largest shareholders are women and the total percentage of women employees in the firm. 


\section{Table 1}

\section{Distribution of Firms (by Industry and MENA Country)}

\begin{tabular}{lccccccc} 
& \multicolumn{7}{c}{ Country } \\
\cline { 2 - 7 } Sector & Algeria & Egypt & Jordan & Morocco & Turkey & Yemen & Total \\
\hline Textiles & 12.47 & 16.91 & 2.85 & 11.60 & 19.15 & 17.77 \\
Garments & 12.21 & & 24.50 & 22.98 & 16.00 & 10.04 & 15.25 \\
Food & 31.43 & & 26.50 & 26.26 & 13.29 & 29.28 & 14.16 \\
Metals and machinery & 28.05 & 19.89 & 6.27 & 0.66 & 18.48 & 16.13 & 18.2 \\
Electronics & 2.34 & 12.01 & 1.99 & 0.44 & 1.39 & 0.09 & 1.67 \\
Chemicals and pharmaceuticals & 8.05 & 7.62 & 10.26 & 20.79 & 4.87 & 3.30 & 5.15 \\
Nonmetallic and plastics & 0.00 & 11.66 & 9.12 & 0.00 & 11.38 & 25.60 & 11.86 \\
Other manufacturing & 5.45 & 31.90 & 18.52 & 17.29 & 15.45 & 15.57 & 15.93 \\
Total & 100 & 100 & 100 & 100 & 100 & 100 & 100
\end{tabular}

NOTE: MENA data refer to individual countries' fiscal years (specified in Table 2). Figures indicate percentages.

SOURCE: World Bank Enterprise Surveys.

\section{Table 2}

\section{Summary Information on the WBES}

\begin{tabular}{|c|c|c|c|c|c|c|}
\hline Country & Survey year & Fiscal year & $\begin{array}{c}\text { No. of } \\
\text { observations }\end{array}$ & $\begin{array}{l}\text { Percent of total } \\
\text { MENA } 8\end{array}$ & $\begin{array}{l}\text { Population } \\
\text { (millions) }\end{array}$ & $\begin{array}{c}\text { Percent of total } \\
\text { MENA } 8\end{array}$ \\
\hline Algeria & 2007 & 2006 & 423 & 10.51 & 36 & 12.84 \\
\hline Egypt & 2008 & 2007 & 1,156 & 28.73 & 82.5 & 29.43 \\
\hline Jordan & 2006 & 2006 & 352 & 8.75 & 6.2 & 2.21 \\
\hline Lebanon & 2009 & 2008 & 140 & 3.48 & 4.3 & 1.53 \\
\hline Morocco & 2006 & 2005 & 466 & 11.58 & 32.3 & 11.52 \\
\hline Syria & 2009 & 2008 & 349 & 8.68 & 20.8 & 7.42 \\
\hline Turkey & 2008 & 2007 & 896 & 22.27 & 73.4 & 26.19 \\
\hline Yemen & 2009 & 2009 & 241 & 5.99 & 24.8 & 8.85 \\
\hline Total MENA 8 & & & 4,023 & 100 & 280.3 & 100 \\
\hline
\end{tabular}

The UNIDO INDSTAT2 database contains industry-level data organized by country, year, and industry and collects information for a large cross section of countries. We focus on the countries in the MENA region during the period the WBESs were collected (see Table 2). The UNIDO INDSTAT2 database contains seven indicators: number of establishments, employment, wages and salaries, output, value added, gross fixed capital formation, and number of female employees. We focus on the total employment (number of employees) and the female labor composition of the workforce by industry (number of female employees). The database adopts 


\section{Contessi, de Nicola, Li}

the International Standard Industrial Classification (ISIC) code system, which classifies industries broadly along product lines (such as food, textiles, iron, and steel). The ISIC code covers all areas of economic activity but data availability constrains us to the manufacturing sector. We use a fairly aggregate level of industry classification at the two-digit level of ISIC Revision 3. 4

The information from UNIDO INDSTAT2 is matched with that from UN COMTRADE, which details annual international trade statistics data by commodities and partner countries. Data availability from the UNIDO INDSTAT2 and UN COMTRADE databases reduces the set of matchable MENA countries to Algeria, Egypt, Jordan, Morocco, and Turkey.

\section{THE FEMALE LABOR CONTENT OF EXPORTS IN AGGREGATE DATA}

Our first step is to construct a country-level measure of the female labor content of exports following the work of Do and Levchenko (2007), which is based on Almeida and Wolfenzon's (2005) approach to measuring the external finance content in production and exports. Do and Levchenko's (2007) measure is based on a model in which a country's comparative advantage contains both a Ricardian component (owing to total factor productivity differences across countries) and a factor proportions component (owing to different country-level endowments of male and female workers related to differences in labor participation).

We follow this approach and compute a sector-level measure of female labor intensity $\left(F L I_{c s}\right)$ that is the share of female labor force at the country-industry level:

$$
F L I_{c s}=\frac{F L_{c s}}{T L_{c s}},
$$

where $F L I_{c s}$ corresponds to the number of female employees in country $c$ and sector $s$ and $T L_{c s}$ represents the number of total workers in country $c$ and sector $s$ as reported in the UNIDO INDSTAT2 database. $\underline{5}$ We then match each sector with the UN COMTRADE data and compute the female labor content in export production as follows:

$$
F L N X_{c s}=\frac{X_{c s}}{X_{c}} F L I_{c s}
$$

where $\frac{X_{c s}}{X_{c}}$ is the share of sector $s$ in total manufacturing exports to the rest of the world by country $c$. Therefore, $F L N X_{c s}$ gives a measure of female labor content of exports from each country/sector pair. Similarly, a country-level measure summarizes the content of female labor in exports for the entire manufacturing sector:

$$
F L N X_{c}=\sum_{s=1}^{s} \frac{X_{c s}}{X_{c}} F L I_{c s} .
$$

Conceptually, the $F L N X_{c}$ measure captures the female labor content of exports, but it also reveals the comparative advantage of individual countries in certain industries. The model developed by Do, Levchenko, and Raddatz (2011) delivers the Heckscher-Ohlin-style prediction that countries with relatively abundant female labor-as measured by female labor force participation-should be observed as exporting relatively larger shares of the goods that make intense 


\section{Figure 6}

\section{Relationship between Comparative Advantage in Female Labor and Industry Export Shares}

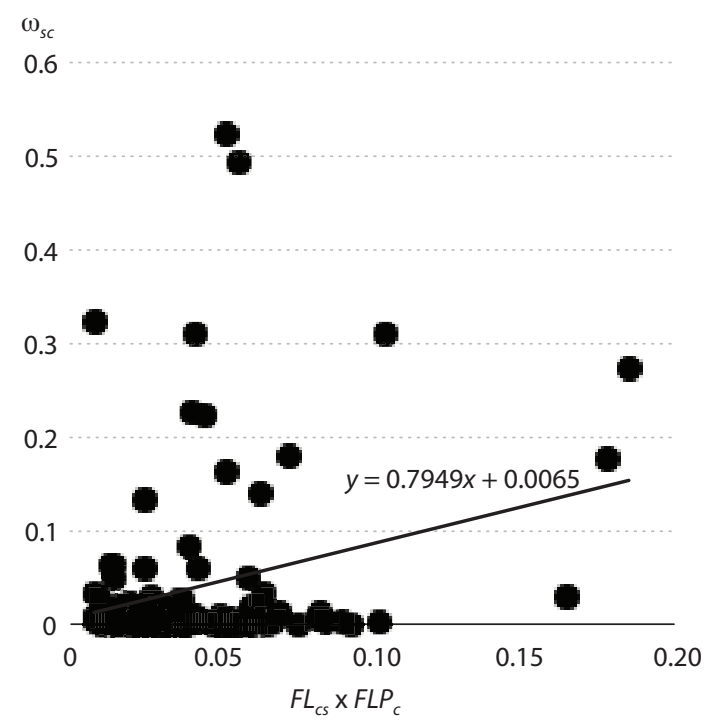

NOTE: Each dot represents a country/industry pair measure. The horizontal axis measures the interaction between female labor participation at the country level and female labor content of exports at the industry level. The vertical axis measures the share of exports in country/industry pair cs in total exports from country $c$.
Figure 7

Female Labor Content of Exports

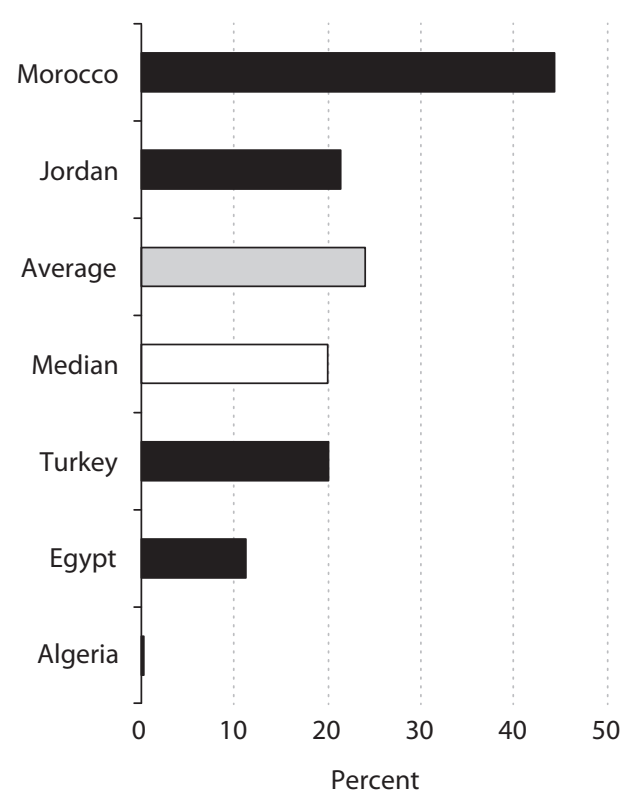

NOTE: Algeria is not included in the measure of the average and median values.

use of female labor. Do, Levchenko, and Raddatz (2011) use cross-sectional country data and find support for this theoretical prediction. Countries with higher female labor force participation show larger export shares in sectors that use female labor intensively, after controlling for country and industry fixed effects. Here, we take a less formal approach to verify whether this fact is confirmed in our sample of countries and years. Figure 6 plots a scatter diagram with the product of each country's female labor participation (FLP) times the female share of total labor for each country/industry pair $(F L)$ on the $x$-axis and the level of export from country/industry pair $c s$ as a share of country $c$ 's total exports $\left(\omega_{c s}=\frac{X_{c s}}{X_{c}}\right)$ on the $y$-axis. $\frac{6}{}$ The solid line indicates the linear interpolation of the scatter dots and shows the positive relationship predicted by the theory. Consistent with the findings of Do, Levchenko, and Raddatz (2012), the solid line in Figure 6 shows a positive relationship between, broadly speaking, female labor participation and exports.

Now a new question arises: Which industries in each country have a comparative advantage in female labor? To answer this question, we pool countries and consider the cross section of sectors and compute the female labor content of exports at the country level (Figure 7). The ranking of industries is determined by pooling all MENA countries for which data are available in the UNIDO INDSTAT 2 database. Figure 8 indicates which sectors are female (male) labor 


\section{Figure 8}

\section{Female Workers as a Share of Total Workers by Industry (Pooling Countries) and MENA Country (Pooling Industries)}
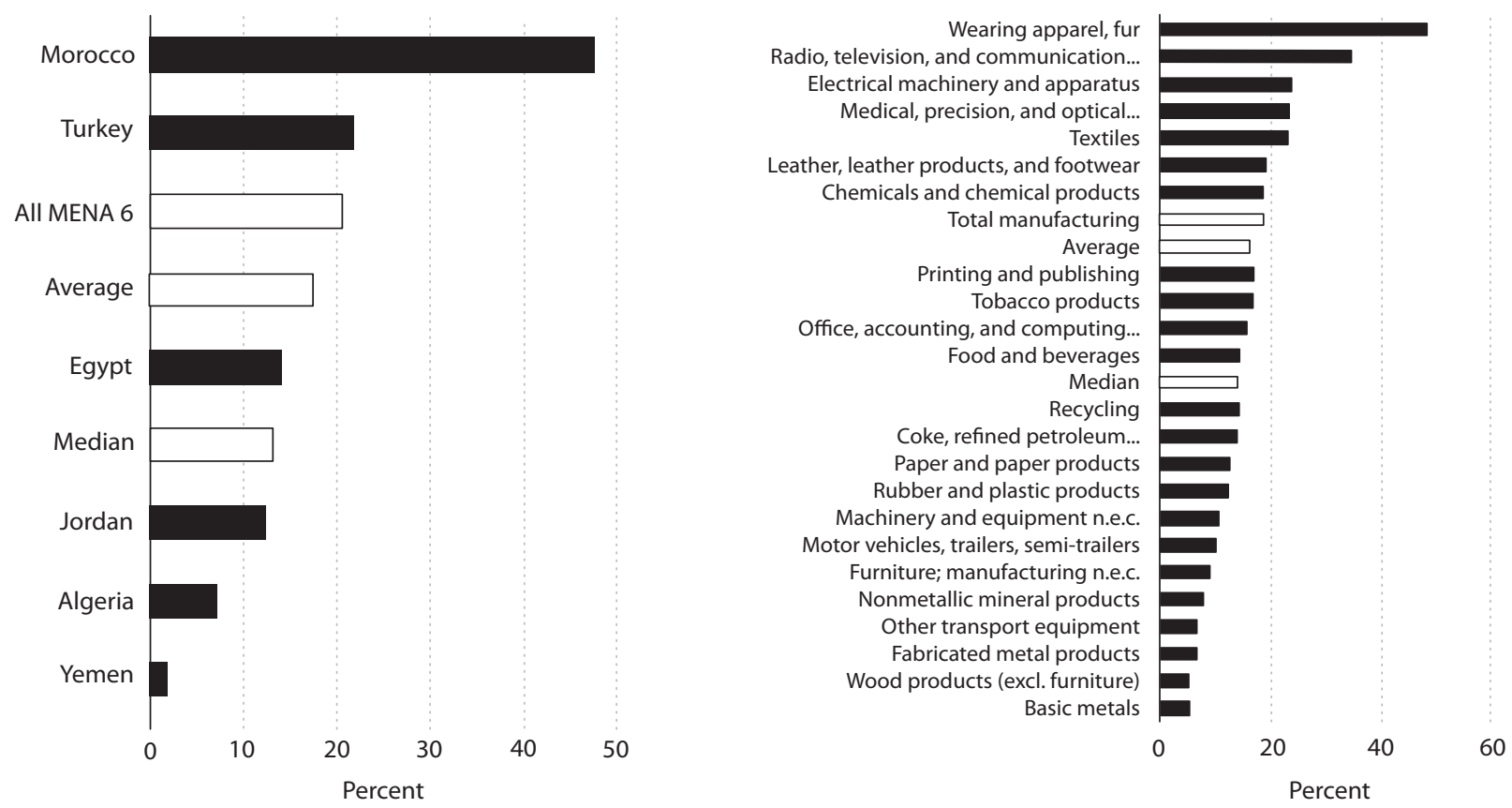

NOTE: n.e.c., not elsewhere classified.

SOURCE: UNIDO.

intensive on average-that is, the sectors that display a higher-than-average share of female (male) labor of the total labor used by industry. ${ }^{\underline{7}}$

The ranking of industries according to female labor intensity by sector and the ranking of countries according to the female labor content of exports at the country level also help us to define the industries in which individual countries have a comparative advantage in female labor relative to the MENA group overall. Morocco and Jordan have a comparative advantage in female-labor-intensive industries, while Egypt and Turkey have a comparative advantage in male-labor-intensive industries. We also consider Algeria as having a comparative advantage in male-labor-intensive industries, although the UNIDO data were available only for 1996; therefore, this country's measures should be considered carefully.

\section{USING FIRM-LEVEL DATA TO IDENTIFY COMPARATIVE ADVANTAGE IN COUNTRY/INDUSTRY PAIRS}

In previous sections, comparative advantage at the country level was defined on the basis of the factor content of trade, particularly focusing on female and male labor as inputs. We continue to assume these are the only two factors of production and abstract from the measurement of capital, given the available data. Our next step is to link our analysis to the firm-level 


\section{Figure 9}

\section{Within-Industry Dispersion of Factor Intensity Measures}

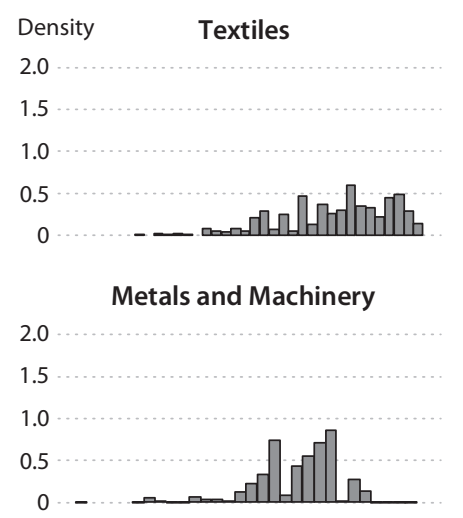

Nonmetallic and Plastic Materials

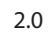

1.5

1.0

0.5

0

0

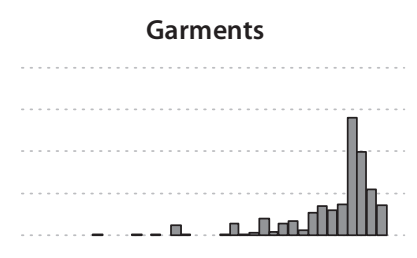

Electronics

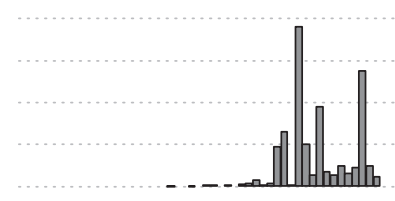

Other Manufacturing

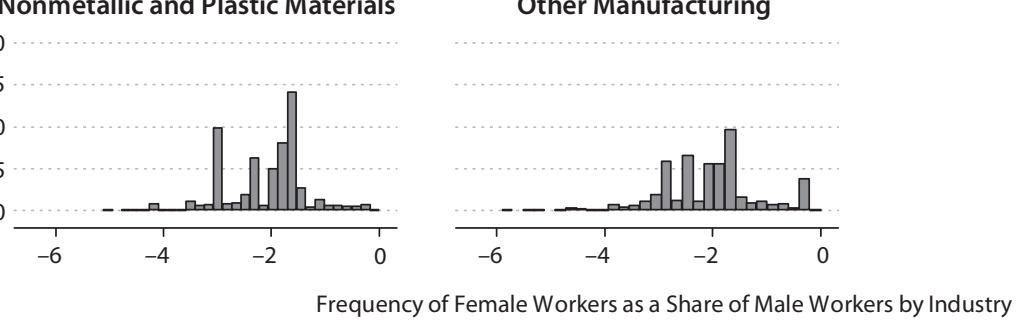

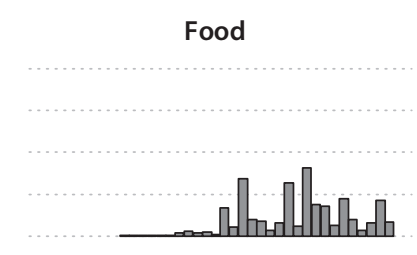

Chemicals and Pharmaceuticals

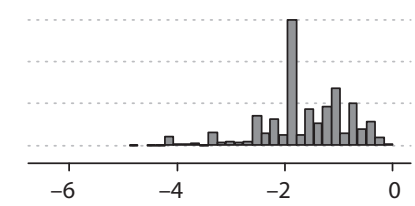

NOTE: Factor intensity is the log of the female-to-male labor ratio.

implications of recent theories of comparative advantage in international trade theory that introduce firm heterogeneity in more standard factors. Typical Heckscher-Ohlin models imply within-industry homogeneity in factor intensity. "New trade theory" approaches with firm heterogeneity usually use models with only labor as a production factor, therefore abstracting from factor intensities. However, the evidence shows that factor intensities vary greatly within industries. For example, Leonardi (2007) documents (i) the wide capital-to-labor ratio dispersion within U.S. industries using Compustat-reported firms and (ii) its upward trend over time and relates the dispersion to the increase in residual wage inequality. Figure 9, for which we use firmlevel data, shows the within-industry dispersion in the female-to-male labor ratio across MENA countries; a vast dispersion is seen both within and between industry sectors. The results hold true when the graphs for each country are plotted separately (not shown). $\underline{8}$

The next step in our analysis considers the following two definitions consistent with Crozet and Trionfetti (2012): (i) Female-labor-intensive industries are those in which the female-tomale labor ratio of the industry is larger than the female-to-male labor ratio for the region. (ii) Female-labor-abundant countries are those in which the female-to-male labor ratio of the country is larger than the female-to-male labor ratio for the region as a whole.

Making these two definitions operational with firm-level data can be challenging because there are multiple ways to measure the female-to-male labor ratio within a country/industry 


\section{Contessi, de Nicola, Li}

pair. The two most intuitive choices are within-country and within-industry averages and median female-to-male labor ratios. However, the within-country/within-industry distributions of firm size are very skewed, which tends to distance the average from the median, and, most importantly, identify country/industry pairs with comparative advantage at odds with the procedure used in the previous sections based on aggregate data. Therefore, we rely on a third option and compute country/industry pair measures of female-to-male labor by first summing workers by gender within a country/industry group and then measuring the ratio. We denote measures constructed using micro data with lowercase letters and aggregate data with capital letters:

$$
f m l_{c s}=\frac{\sum_{i \in c s} f l_{i c s}}{\sum_{i \in c s} m l_{i c s}},
$$

where $i, c$, and $s$ denote firms, countries, and industries, respectively. We have country/industry pairs for 8 sectors times 5 countries and corresponding measures of the female-to-male labor ratio $f m l r_{c s}$. We then sum the firm-level female employment and male employment within a country across industries $f m l r_{c}$ and across countries in the same industry fmlr $r_{s}$. We obtain the female-to-male labor ratio by summing female and male workers across sectors and countries. A sector is female labor intensive if $f m l r_{s}>f m l r$, while a country is female labor abundant if $f m l r_{c}>f m l r$.

These definitions identify the country/industry pairs with comparative advantage in either female or male labor (Table 3). Panel A of the table reports the female-to-male labor ratio measures and identifies the country/industry pairs with comparative advantage in female labor based on (i) firm-level data in Panel B (identified by a dummy variable called DV-CA micro) and (ii) aggregate data and the measure of the female labor content of exports (Panel C) developed by Do, Levchenko, and Raddatz (2012). The table shows that the partition of countries using micro and aggregate data delivers the same classification of countries in female-labor-abundant and male-labor-abundant industries except for the chemicals and pharmaceutical industry. It should be noted that this industry measure of female labor intensity is particularly close to the total manufacturing measure (see Figure 8) based on aggregate data; this finding suggests that the mismatch between classifications may be influenced by small differences between the firm-level and aggregate data.

More generally, our match shows that the firm-level surveys could be used to define comparative advantage country/industry pairs even when the aggregate data are not available, a result we plan to exploit in future research. In this article, we use this methodology to add another country for which we have firm-level data to our set of countries for the remainder of the analysis.

Before we use these classifications of country/industry pairs in our firm-level analysis, we discuss some evidence on hiring practices related to the gender of workers and managers based on the Jordanian WBES for 2006 in the boxed insert.

\section{Female Entrepreneurship}

We investigate the main factors that hinder a firm's operation and growth to better grasp the business environment faced by firms. WBES respondents identify "the biggest obstacle for 
Contessi, de Nicola, Li

\section{Table 3}

\section{Determination of Country/Industry Pairs: Comparative Advantage Industries Using Firm-Level Data}

\begin{tabular}{|c|c|c|c|c|c|c|c|c|}
\hline \multirow[b]{2}{*}{ Sector } & \multicolumn{6}{|c|}{ Country } & \multirow[b]{2}{*}{$f m / r_{s}$} & \multirow[b]{2}{*}{$\begin{array}{l}\text { Industry } \\
\text { classification }\end{array}$} \\
\hline & Turkey & Egypt & Morocco & Jordan & Algeria & Yemen & & \\
\hline \multicolumn{9}{|l|}{ Panel A: $\mathbf{f m} / \mathbf{r}$} \\
\hline Textiles & 0.39 & 0.21 & 1.71 & 0.72 & 0.57 & & 0.38 & FL-INT \\
\hline Garments & 1.02 & & 2.96 & 0.94 & 0.72 & 0.10 & 1.05 & FL-INT \\
\hline Food & 0.25 & & 0.41 & 0.08 & 0.20 & 0.07 & 0.24 & ML-INT \\
\hline Metals and machinery & 0.11 & 0.08 & 0.06 & 0.03 & 0.09 & 0.01 & 0.10 & ML-INT \\
\hline Electronics & 0.19 & 0.79 & 1.11 & 0.07 & 0.19 & 0.00 & 0.36 & FL-INT \\
\hline Chemicals and pharmaceuticals & 0.19 & 0.45 & 0.56 & 0.17 & 0.09 & 0.53 & 0.28 & ML-INT \\
\hline Nonmetallic and plastic materials & 0.14 & 0.20 & & 0.02 & & 0.03 & 0.14 & ML-INT \\
\hline Other manufacturing & 0.06 & 0.27 & 0.42 & 0.11 & 0.11 & 0.04 & 0.10 & ML-INT \\
\hline$f m / r_{c}$ & 0.303 & 0.256 & 1.070 & 0.431 & 0.199 & 0.068 & 0.305 & \\
\hline Country classification & $M L-A B$ & $M L-A B$ & FL-AB & FL-AB & $M L-A B$ & $M L-A B$ & & \\
\hline
\end{tabular}

\section{Panel B: DV-CA micro}

Textiles

Garments

Food

Metals and machinery

Electronics

Chemicals and pharmaceuticals

Nonmetallic and plastic materials

Other manufacturing

$\begin{array}{llllll}0 & 0 & 1 & 1 & 0 & \\ 0 & & 1 & 1 & 0 & 0 \\ 1 & & 0 & 0 & 1 & 1 \\ 1 & 1 & 0 & 0 & 1 & 1 \\ 0 & 0 & 1 & 1 & 0 & 0 \\ 1 & 1 & 0 & 0 & 1 & 0 \\ 1 & 1 & & 0 & & 1 \\ 1 & 1 & 0 & 0 & 1 & 1\end{array}$

\section{Panel C: DV-CA macro}

Textile

Food

Metals and machinery

Electronics

Chemicals and pharmaceuticals

Nonmetallic and plastic products

Other manufacturing

Country classification
Garments

\begin{tabular}{|c|c|c|c|c|}
\hline 0 & 0 & 1 & 1 & \\
\hline 0 & 0 & 1 & 1 & \\
\hline 1 & 1 & 0 & 0 & \\
\hline 1 & 1 & 0 & 0 & \\
\hline 0 & 0 & 1 & 1 & \\
\hline 0 & 0 & 1 & 1 & \\
\hline 1 & 1 & 0 & 0 & \\
\hline 1 & 1 & 0 & 0 & \\
\hline ML-AB & $M L-A B$ & FL-AB & FL-AB & ML-AB \\
\hline
\end{tabular}

NOTE: The three panels compare the determination of country/industry pairs with comparative advantage (identified as "1") using aggregate and firm-level data. FL-AB, female-labor-abundant relative to the group of countries; ML-AB, male-labor-abundant relative to the group of countries; FL-INT, female-labor-intensive relative to the manufacturing sector as a whole; ML-INT, male-labor-intensive relative to the manufacturing sector as a whole. 


\section{Hiring Practices Related to the Gender of Workers and Managers in Jordan}

According to our classification of countries based on the aggregate data, Jordan is abundant in male labor relative to other countries in the MENA group (Figure 10). The classification also reveals a relatively high number of legal differentiations affecting female workers and entrepreneurs (see Figure 1), a low female labor participation rate (see Figure 2), and a low incidence of female ownership among entrepreneurs. These findings are highly consistent with the firm-level data from the WBESs.

Several indicators suggest that firms' hiring preferences are biased in favor of male workers. Here we exploit a unique section of the Jordanian WBES that further details the respondents' explanations for such bias. They were directly asked whether they prefer to hire male or female workers; the number of firms that preferred to hire men as production workers is about 4.4 times larger than those that preferred to hire women. This measure is in line with the country-level data showing that the participation rate of male workers is about 4.3 times larger than that of female workers (see Figure 2). More interestingly, this bias varies among exporters and non-exporters (Figure B1) and establishments with female ownership and those without female ownership (Figure B2). As Figure B2 shows, exporters and establishments with female ownership have a higher tendency to hire women and a higher percentage of reporting managers indifferent about gender preferences in recruitment.

\section{Figure B1}

Percent of Valid Responses

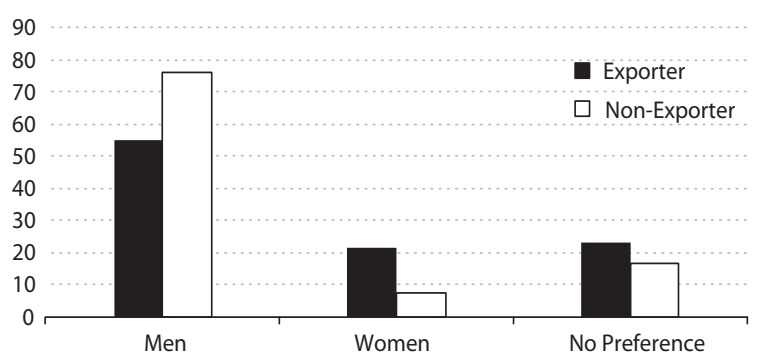

\section{Figure B2}

Percent of Valid Responses

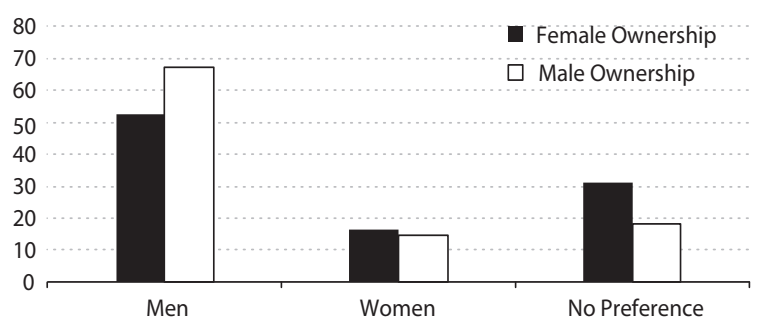

SOURCE: World Bank Enterprise Survey.

In addition, the surveyed firms reported the reasons for their preferences for male or female workers; the major reasons tend to be similar. They also list the three most important reasons for their preference to hire men (or alternatively, women) after answering the question on their gender-based recruiting preferences. Figure B3 plots the percentage of answers to "the most important reason" question. The top-rated reason is "productivity." Somewhat surprisingly, the second most important reason is listed as "other-specify," which once deconstructed consists essentially of answers that can be combined as "nature of the job/business" followed by "flexibility" and "lower rates of absenteeism." The fact that productivity ranks high for both male and female workers supports the sector-specific technological bias in favor of

\section{Figure B3: The Most Important Reason to Hire Men/Women}

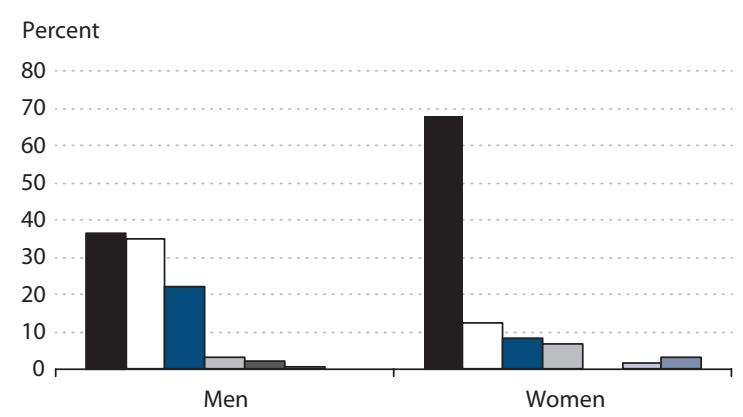

SOURCE: World Bank Enterprise Survey.

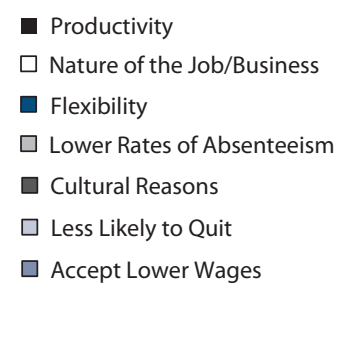

- Productivity

$\square$ Nature of the Job/Business

$\square$ Flexibility

Lower Rates of Absenteeism

ltural Reasons

Less Likely to Quit

Accept Lower Wages either male or female workers. 


\section{Figure B4: Reasons to Prefer to Hire Men (Pooling Reasons)}

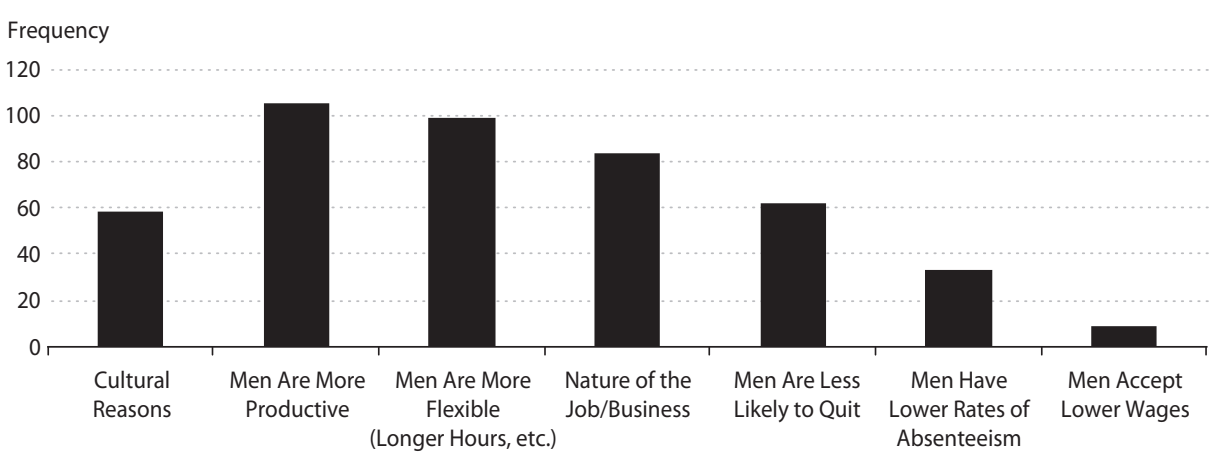

NOTE: The World Bank Enterprise Survey asks respondents to provide the three most important reasons for their preferences to hire men (or alternatively, women). The authors pooled all answers from the three most important reasons and assigned equal weights to each answer.

SOURCE: World Bank Enterprise Survey.

\section{Figure B5: The Most Important Reason the Establishment Prefers to Hire Men}

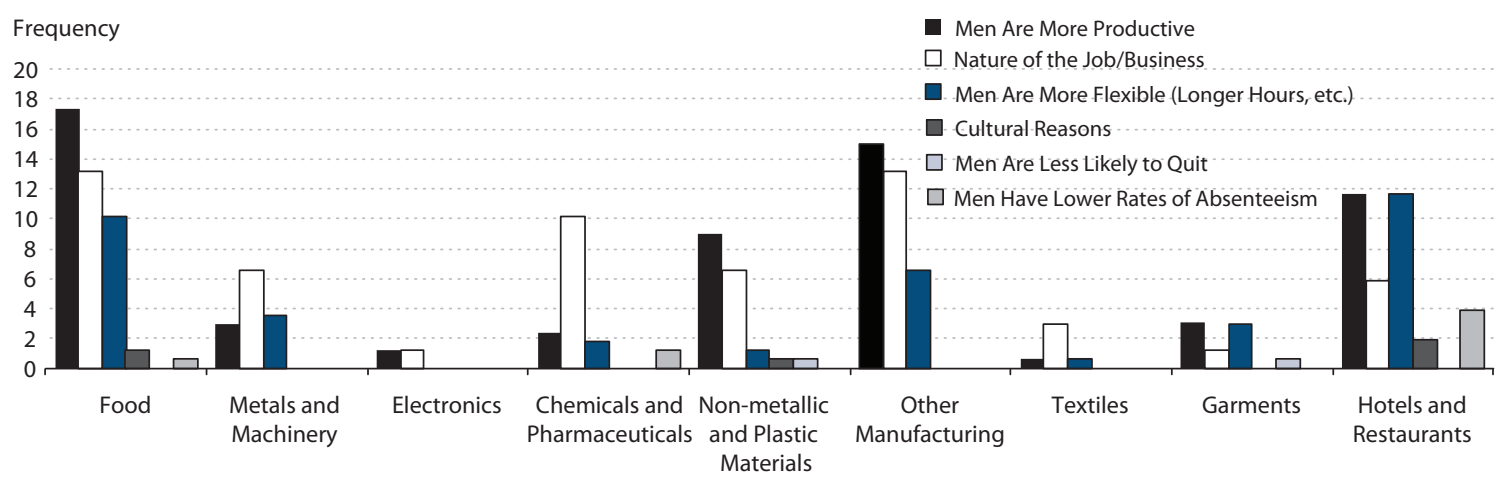

SOURCE: World Bank Enterprise Survey.

"Cultural reasons" play a less important role in influencing the hiring process compared with other factors as this is listed as the third most important reason to hire men as production workers. When we pool the entire set of the three most important reasons, "cultural reasons" ranks fifth among the major reasons (Figure B4), accounting for 13 percent of total responses. Among the cultural reasons, "Men have to support families" accounts for 76 percent of the responses after pooling the three most important reasons. This finding is highly consistent with the answers to the binary gender differentiation question - "Can a married woman be 'head of a household' or 'head of a family' in the same way as a man?"-in the WBL data.

Finally, the survey supports the view that technology and industries may be brawn-labor biased (Figure B5) even if there is some discrimination because of cultural values. After pooling the reasons, "nature of the job/business," which usually means that the job requires physical effort, ranks third overall (see Figure B4) and is second in "the most important reason" category (see Figure B3) for firms that prefer to hire men as production workers. Figure B5 shows that "nature of the job/business" is one of the leading factors in male-labor-intensive industries (such as food, metals and machinery, nonmetallic and plastic materials, and other manufacturing) in which female-to-total labor ratios are below average (see Figure 8) in a male-abundant country such as Jordan. Therefore, the low female participation rates may be partially explained by the higher demand for brawn labor than brain labor in these industries. 
Contessi, de Nicola, Li

\section{Figure 10}

Female Workers as a Share of Total Workers (by Country)

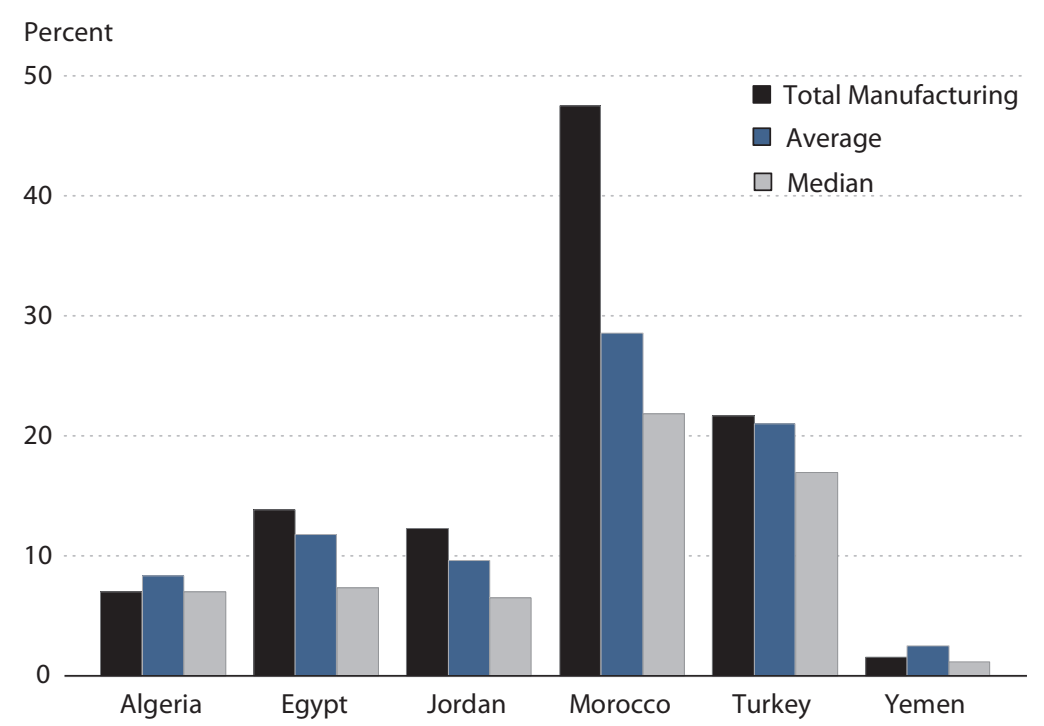

SOURCE: World Bank Enterprise Surveys.

\section{Figure 11}

“What Is the Biggest Obstacle for the Operation and Growth of Your Establishment?" (Responses by Gender)

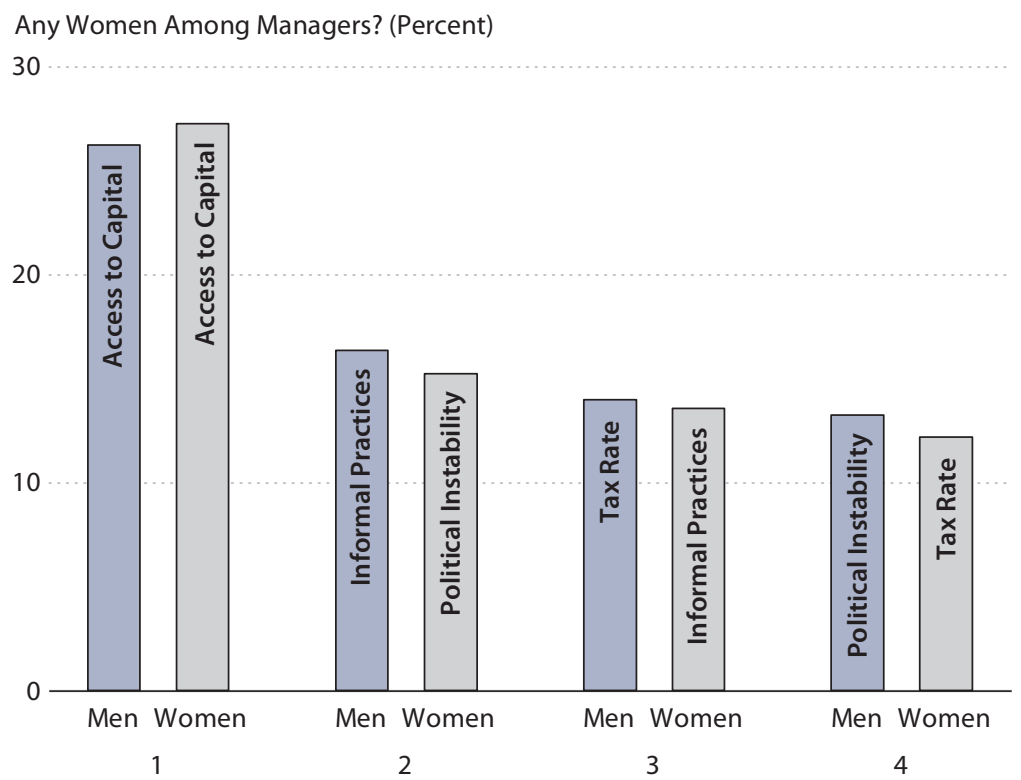




\section{Figure 12}

\section{"What Is the Biggest Obstacle for the Operation and Growth of Your Establishment?" (Responses by Country and Respondent Gender)}
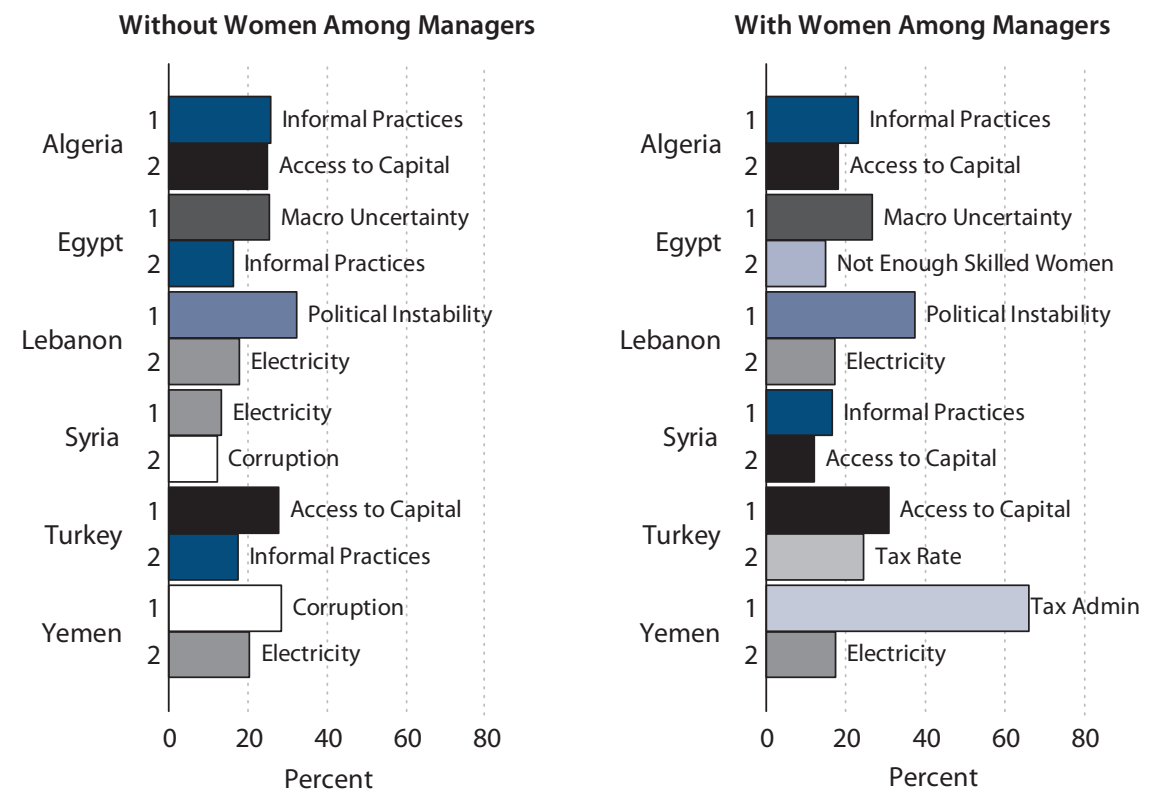

NOTE: The figure shows the four most frequently mentioned constraints by countries and firms with and without women as managers.

the operation and growth of [the] establishment" from an extensive country-specific list of possible constraints to business. 9 Figure 11 plots the survey answers according to whether the firm has any female managers. Interestingly, access to capital is the most frequent issue raised by firms regardless of the gender composition of management. Political instability, high tax rates, and illegal or unfair competition from the informal sectors (such as smuggling or dumping) are also cited by both types of firms. However, there is more heterogeneity in the relative importance of these issues across firm types. Firms with women in management place more importance on political instability and less on the competition from the informal sector or high tax rates.

The WBESs provide a representative sample of firms within but not necessarily across countries (see Table 2 for a cross-country comparison of the representativeness of our data). Figure 12 plots the two most frequent answers by country and gender of the respondent to uncover the possible presence of country-specific differences masked by the aggregates. The main constraint to business is the same for male- and female-managed firms in all MENA countries except Syria and Yemen; in Syria women suffer more because of competition from the informal sector, and the Yemenite complicated taxation policies are the most-reported barrier by female-managed firms. The second most important constraint is somewhat different across countries and gender composition of a firm's management. Algeria and Lebanon are the only exceptions where access to capital and electricity, respectively, is always difficult. 


\section{Table 4}

“Do Business Constraints Have a Differential Impact on Firms Managed by Women?”

\begin{tabular}{|c|c|c|c|c|c|}
\hline \multirow[b]{2}{*}{ Controls } & \multicolumn{5}{|c|}{ Constraints } \\
\hline & $\begin{array}{c}\text { Macro } \\
\text { uncertainty }\end{array}$ & Tax rate & Corruption & $\begin{array}{l}\text { Informal } \\
\text { practices }\end{array}$ & $\begin{array}{l}\text { Not enough } \\
\text { skilled women }\end{array}$ \\
\hline \multirow[t]{2}{*}{ Women manager? Yes = 1} & $0.19^{* *}$ & 0.01 & -0.01 & -0.15 & -0.15 \\
\hline & $(0.07)$ & $(0.15)$ & $(0.20)$ & $(0.27)$ & $(0.28)$ \\
\hline \multirow[t]{2}{*}{ Exporter? Yes = 1} & $0.21^{* *}$ & 0.19 & 0.19 & 0.02 & 0.1 \\
\hline & $(0.09)$ & $(0.14)$ & $(0.20)$ & $(0.16)$ & $(0.14)$ \\
\hline \multirow[t]{2}{*}{ No. } & 1,192 & 2,145 & 2,124 & 2,277 & 2,334 \\
\hline & Electricity & Tax administration & Access to capital & $\begin{array}{c}\text { Labor } \\
\text { regulations }\end{array}$ & Business licensing \\
\hline \multirow[t]{2}{*}{ Women manager? Yes = 1} & 0.07 & -0.21 & $0.27^{*}$ & 0.13 & -0.05 \\
\hline & $(0.20)$ & $(0.27)$ & $(0.15)$ & $(0.26)$ & $(0.15)$ \\
\hline \multirow[t]{2}{*}{ Exporter? Yes = 1} & -0.14 & $0.29 * *$ & $-0.33^{* *}$ & 0.18 & 0.12 \\
\hline & $(0.18)$ & $(0.15)$ & $(0.15)$ & $(0.15)$ & $(0.20)$ \\
\hline \multirow[t]{2}{*}{ No. } & 2,303 & 2,140 & 1,851 & 2,314 & 2,131 \\
\hline & Customs regulations & Legal system & Transportation & Telecommunications & Crime \\
\hline \multirow[t]{2}{*}{ Women manager? Yes = 1} & -0.19 & -0.13 & -0.07 & $-0.22^{* *}$ & 0.16 \\
\hline & $(0.20)$ & $(0.28)$ & $(0.08)$ & $(0.09)$ & $(0.20)$ \\
\hline \multirow[t]{2}{*}{ Exporter? Yes = 1} & $0.57^{* * *}$ & 0.29 & -0.14 & 0.05 & -0.01 \\
\hline & $(0.19)$ & $(0.20)$ & $(0.17)$ & $(0.10)$ & $(0.17)$ \\
\hline No. & 1,870 & 1,980 & 1,657 & 1,161 & 2,251 \\
\hline
\end{tabular}

NOTE: Ordered probit, marginal effect. The regressions include the following variables (not displayed): dummy for exporter, age of the firm, total employment $(\mathrm{log})$, total sales $(\mathrm{log})$, and labor productivity $(\mathrm{log})$. Robust standard errors are reported in parentheses. ${ }^{*},{ }^{* *}$, and ${ }^{* * *}$ indicate significance at the 10 percent, 5 percent, and 1 percent levels, respectively.

We test this descriptive evidence to gain further insights. Respondents to the WBESs not only identified the two most important constraints to business, but they also ranked all possible business constraints in order of importance. In particular, they were asked to determine whether each constraint was "not an obstacle" or a "minor, moderate, severe, or very severe obstacle." We used the answers to these qualitative questions to construct an index ranging from 0 to 4 to indicate the importance of each business constraint. $\underline{10}$ We used these answers and added firmlevel controls (such as the firm age, labor productivity, and size) to determine whether there are significant systematic differences across gender (Tables 4 and 5). Firms with female managers appear to have fewer telecommunication problems but face greater macroeconomic uncertainty (i.e., uncertainty about inflation and exchange rate fluctuations) and have more problems in obtaining access to financing (e.g., because of insufficient collateral); the latter result is likely related to the fact that firms managed by women tend to be smaller. While macroeconomic uncertainty harms exporters as expected, access to capital is more problematic for non-exporters; 


\section{Table 5}

“Do Business Constraints Have a Differential Impact on Firms Owned by Women?”

\begin{tabular}{|c|c|c|c|c|c|}
\hline \multirow[b]{2}{*}{ Controls } & \multicolumn{5}{|c|}{ Constraints } \\
\hline & $\begin{array}{c}\text { Macro } \\
\text { uncertainty }\end{array}$ & Tax rate & Corruption & $\begin{array}{l}\text { Informal } \\
\text { practices }\end{array}$ & $\begin{array}{l}\text { Not enough } \\
\text { skilled women }\end{array}$ \\
\hline \multirow[t]{2}{*}{ Women owner? Yes = 1} & 0.01 & - & 0.18 & -0.08 & 0 \\
\hline & $(0.14)$ & - & $(0.14)$ & $(0.16)$ & $(0.13)$ \\
\hline \multirow[t]{2}{*}{ Exporter? Yes = 1} & 0.06 & - & 0.22 & 0.03 & 0.11 \\
\hline & $(0.11)$ & - & $(0.19)$ & $(0.16)$ & $(0.15)$ \\
\hline \multirow[t]{2}{*}{ No. } & 605 & - & 1,564 & 1,700 & 1,776 \\
\hline & Electricity & Tax administration & Access to capital & $\begin{array}{l}\text { Labor } \\
\text { regulations }\end{array}$ & Business licensing \\
\hline \multirow[t]{2}{*}{ Women owner? Yes = 1} & $-0.27^{*}$ & - & $0.25^{* *}$ & 0.04 & $0.32^{* *}$ \\
\hline & $(0.14)$ & - & $(0.12)$ & $(0.15)$ & $(0.14)$ \\
\hline \multirow[t]{2}{*}{ Exporter? Yes = 1} & -0.17 & - & $-0.31^{* *}$ & 0.2 & 0.14 \\
\hline & $(0.18)$ & - & $(0.15)$ & $(0.15)$ & $(0.20)$ \\
\hline \multirow[t]{2}{*}{ No. } & 1,772 & - & 1,682 & 1,760 & 1,579 \\
\hline & Customs regulations & Legal system & Transportation & Telecommunications & Crime \\
\hline \multirow[t]{2}{*}{ Women owner? Yes = 1} & -0.16 & 0.01 & 0.11 & -0.19 & -0.01 \\
\hline & $(0.16)$ & $(0.15)$ & $(0.36)$ & $(0.15)$ & $(0.16)$ \\
\hline \multirow[t]{2}{*}{ Exporter? Yes = 1} & $0.60 * * *$ & 0.28 & -0.24 & 0.14 & -0.01 \\
\hline & $(0.20)$ & $(0.20)$ & $(0.25)$ & $(0.11)$ & $(0.17)$ \\
\hline No. & 1,581 & 1,104 & 772 & 614 & 1,694 \\
\hline
\end{tabular}

NOTE: Ordered probit, marginal effect. The regressions include the following variables (not displayed): dummy for exporter, age of the firm, total employment $(\log )$, total sales $(\log )$, and labor productivity $(\log )$. Robust standard errors are reported in parentheses. ${ }^{*},{ }^{* *}$, and ${ }^{* * *}$ indicate significance at the 10 percent, 5 percent, and 1 percent levels, respectively.

such lack of access is consistent with the notion of selection into export. Access to capital remains more difficult for enterprises owned by women than those owned by men. Macroeconomic conditions lose their relevance, but obtaining business licensing becomes more difficult for women and access to electricity gains importance for male owners.

Finally, we investigate whether trade plays a role in empowering women. Specifically, we analyze (i) whether women are more likely to be business owners or managers of a company (Table 6) and (ii) whether the existence of comparative advantage in a sector affects the likelihood of women being business owners in that sector (Table 7). We find evidence suggesting women are likely to advance professionally in sectors in which their presence is stronger. We find evidence that suggests women are likely to climb professional ladders in sectors where their presence is stronger, a fact that is consistent with the evidence analyzed in Golan, Gayle, and Miller (2012). In our analysis, this empowerment through employment narrative is motivated by the positive and significant correlation (the point estimate is 0.21 with a corresponding 


\section{Table 6}

Does Trade Empower Female Managers or Owners?

\begin{tabular}{|c|c|c|c|c|}
\hline Regressors & \multicolumn{2}{|c|}{ Women owner? Yes = 1} & \multicolumn{2}{|c|}{ Women manager? Yes = 1} \\
\hline Firm-level female labor share & $\begin{array}{c}0.21^{*} \\
(0.12)\end{array}$ & & $\begin{array}{l}0.10^{* *} \\
(0.04)\end{array}$ & \\
\hline Female-labor-intensive sector & & $\begin{array}{c}0.04 \\
(0.06)\end{array}$ & & $\begin{array}{c}-0.03 \\
(0.03)\end{array}$ \\
\hline Log(Employment) & $\begin{array}{c}-0.61 \\
(0.63)\end{array}$ & $\begin{array}{c}-0.62 \\
(0.62)\end{array}$ & $\begin{array}{c}-0.33 \\
(0.26)\end{array}$ & $\begin{array}{c}-0.38 \\
(0.25)\end{array}$ \\
\hline Age & $\begin{array}{l}0 \\
(0.00)\end{array}$ & $\begin{array}{l}0 \\
(0.00)\end{array}$ & $\begin{array}{l}0 \\
(0.00)\end{array}$ & $\begin{array}{c}0 \\
(0.00)\end{array}$ \\
\hline $\log (M P L)$ & $\begin{array}{c}-0.67 \\
(0.61)\end{array}$ & $\begin{array}{c}-0.69 \\
(0.60)\end{array}$ & $\begin{array}{c}-0.33 \\
(0.25)\end{array}$ & $\begin{array}{r}-0.40^{*} \\
(0.24)\end{array}$ \\
\hline Log(Sales) & $\begin{array}{c}0.65 \\
(0.61)\end{array}$ & $\begin{array}{c}0.68 \\
(0.60)\end{array}$ & $\begin{array}{c}0.31 \\
(0.25)\end{array}$ & $\begin{array}{c}0.38 \\
(0.24)\end{array}$ \\
\hline Mean dependent variable & 0.37 & 0.37 & 0.08 & 0.07 \\
\hline No. & 2,185 & 1,921 & 2,336 & 2,076 \\
\hline
\end{tabular}

$p$-value of 0.0000) between the average share of female employment and the average share of female-owned firms by sector and country that results after controlling for other observable characteristics of the firm (see Table 7).

Female owners are more likely to be observed in industries with a higher presence of female workers or in female-labor-intensive industries (with a larger-than-the-median share of female workers). These results, however, are not economically or statistically significant. Conversely, we find that women are significantly more likely to be managers of firms with lower labor productivity.

Table 6 also accounts for the role of the de jure constraints analyzed in a previous section. We construct an index between 0 and 1 where 1 (0) corresponds to the maximum (minimum) number of de jure constraints faced by women in a given country. As expected, women are more likely to become business owners in female-labor-abundant countries when they face fewer de jure constraints and operate in industries with a higher concentration of female workers. The negative effect of de jure constraints is reduced for women when they are employed in a femalelabor-intensive sector.

\section{CONCLUSION}

This article contributes to the small but growing literature on the relationship between female labor participation and openness to globalization. We focus on two aspects of this relationship: the analysis of comparative advantage in female labor using both aggregate and firmlevel data and the role of trade openness in favoring female entrepreneurship and ownership. 


\section{Table 7}

Trade or De Jure Constraints: What Empowers Female Managers or Owners?

\begin{tabular}{|c|c|c|c|c|}
\hline \multirow{2}{*}{$\frac{\text { Regressors }}{\text { Index of de jure constraints }}$} & \multicolumn{4}{|c|}{$\begin{array}{c}\text { Female Owners? Yes }=1 \\
\text { FL-AB Countries (Morocco and Jordan) }\end{array}$} \\
\hline & $\begin{array}{c}-0.09^{*} \\
(0.05)\end{array}$ & $\begin{array}{l}-0.12^{* *} \\
(0.06)\end{array}$ & $\begin{array}{l}0 \\
(0.04)\end{array}$ & $\begin{array}{l}-0.05 \\
(0.05)\end{array}$ \\
\hline Female-to-male labor ratio & $\begin{array}{l}0.05^{* * *} \\
(0.02)\end{array}$ & $\begin{array}{c}-0.05 \\
(0.06)\end{array}$ & & \\
\hline $\begin{array}{l}\text { Index of de jure constraints } \times \text { Female-to-male } \\
\text { labor ratio }\end{array}$ & & $\begin{array}{l}0.10^{*} \\
(0.06)\end{array}$ & & \\
\hline Female labor intensive & & & $\begin{array}{c}0.05^{*} \\
(0.03)\end{array}$ & $\begin{array}{c}-0.04 \\
(0.05)\end{array}$ \\
\hline De jure constraints $\times$ Female labor intensive & & & & $\begin{array}{l}0.13^{* *} \\
(0.06)\end{array}$ \\
\hline Log(Employment) & $\begin{array}{l}0.34^{* *} \\
(0.17)\end{array}$ & $\begin{array}{l}0.33^{* *} \\
(0.16)\end{array}$ & $\begin{array}{l}0.30^{* *} \\
(0.15)\end{array}$ & $\begin{array}{l}0.31^{* *} \\
(0.15)\end{array}$ \\
\hline Age & $\begin{array}{l}0 \\
(0.00)\end{array}$ & $\begin{array}{l}0 \\
(0.00)\end{array}$ & $\begin{array}{l}0 \\
(0.00)\end{array}$ & $\begin{array}{l}0 \\
(0.00)\end{array}$ \\
\hline $\log (M P L)$ & $\begin{array}{l}0.33^{* *} \\
(0.17)\end{array}$ & $\begin{array}{c}0.32^{*} \\
(0.16)\end{array}$ & $\begin{array}{c}0.28^{*} \\
(0.15)\end{array}$ & $\begin{array}{c}0.29^{*} \\
(0.15)\end{array}$ \\
\hline Log(Sales) & $\begin{array}{c}-0.33^{* *} \\
(0.16)\end{array}$ & $\begin{array}{c}-0.32^{* *} \\
(0.16)\end{array}$ & $\begin{array}{c}-0.28^{* *} \\
(0.14)\end{array}$ & $\begin{array}{c}-0.29^{*} \\
(0.15)\end{array}$ \\
\hline Mean dependent variable & 0.14 & 0.14 & 0.14 & 0.14 \\
\hline No. & 775 & 775 & 775 & 775 \\
\hline
\end{tabular}

NOTE: Probit, marginal effect. Robust standard errors are reported in parentheses. FL-AB, female-labor-abundant relative to the group of countries; MPL, marginal productivity of labor. * ${ }^{* *}$, and ${ }^{* * *}$ indicate significance at the 10 percent, 5 percent, and 1 percent levels, respectively.

We focus specifically on MENA countries because they represent a somewhat extreme case in international comparisons of de jure obstacles to female employment and entrepreneurship and have low female labor participation and low female entrepreneurship and ownership rates. We use a novel approach to match the classification of country/industry pairs with comparative advantage based on aggregate data with a corresponding definition in firm-level data from the WBESs. Our approach suggests a fruitful avenue for research when aggregate data are not available and researchers are interested in identifying country/industry pairs with and without comparative advantage in certain factors that may be available in micro data (for example, high- and low-skilled labor). We provide informal evidence of a link between a country's specialization and its measures of female labor participation consistent with theories of brain-based technological bias and comparative advantage.

Finally, we use the classification of countries and industries according to their comparative advantage to test a form of female empowerment through export orientation. That is, we test whether women are more likely to be entrepreneurs in industries characterized by comparative advantage in female labor in countries where female labor is relatively abundant. We find that women are more likely to be business owners in female-labor-abundant countries when they face fewer de jure constraints and operate in industries with a higher concentration of female 


\section{Contessi, de Nicola, Li}

workers. The negative effect of de jure constraints is dwarfed by being employed in a femalelabor-intensive sector.

We leave to future researchers the broader extension of our results to a model of international trade with a specific role for female labor in countries beyond the MENA region.

\section{NOTES}

1 These data are available at http://wbl.worldbank.org/.

$\underline{2}$ The survey questions reflected in these graphs are (i) Can a married woman apply for a passport in the same way as a man? (ii) Can a married woman travel outside the country in the same way as a man? (iii) Can a married woman travel outside her home in the same way as a man? (iv) Can a married woman get a job or pursue a trade or profession in the same way as a man? (v) Can a married woman sign a contract in the same way as a man? (vi) Can a married woman register a business in the same way as a man? (vii) Can a married woman be "head of household" or "head of family" in the same way as a man? (viii) Can a married woman confer citizenship on her children in the same way as a man? (ix) Can a married woman open a bank account in the same way as a man? (x) Can a married woman choose where to live in the same way as a man? Similar questions are available for unmarried women but are not shown here.

$\underline{3}$ The databases are available at www.enterprisesurveys.org (WBES), www.unido.org/Data1/Statistics/Databases/ISAV.cfm?dig=2 (UNIDO INDSTAT2), and http://comtrade.un.org/ (UN COMTRADE).

4 Industry classification changes across countries, although it is fairly consistent for the five MENA countries available.

$\underline{5}$ Data at the industry level are available and comparable for Egypt, Jordan, Morocco, Turkey, and — with some limitations-Algeria.

$\underline{6}$ The interaction between FLP and FL provides a measure of comparative advantage. Similar indicators are used in Romalis (2004) and Do, Levchenko, and Raddatz (2011).

$\underline{z}$ The female-labor-intensive industries are chemicals and chemical products; leather, leather products, and footwear; textiles; medical, precision, and optical instruments; electrical machinery and apparatus; radio, television, and communication equipment; and wearing apparel, fur. The male-labor-intensive sectors are basic metals; wood products (excluding furniture); fabricated metal products; other transport equipment; nonmetallic mineral products; furniture, manufacturing not elsewhere classified; motor vehicles, trailers, semi-trailers; machinery and equipment not elsewhere classified; rubber and plastics products; paper and paper products; coke, refined petroleum products, and nuclear fuel; recycling; food and beverages; office, accounting, and computing machinery; tobacco products; and printing and publishing.

$\underline{8}$ There is little research explaining this within-industry dispersion of factor intensities in a trade context. At least two factors of production and heterogeneous productivity must be postulated to generate within-industry dispersion of factor intensity. In an open economy, Bernard et al. (2007), Harrigan and Reshef (2011), and Burstein and Vogel (2012) model heterogeneous firms that use multiple inputs in the production function, thereby moving beyond the standard Melitz (2003) approach. Both papers focus on two inputs-high- and low-skilled labor-and discuss the relationship between factor intensity and trade. Bernard et al. (2007) show that standard Heckscher-Ohlin results carry over to a framework with heterogeneous total factor productivity. Burstein and Vogel (2012) show how heterogeneous firms' decisions shape the factor content of trade, the changes in relative factor prices, and between-sector factor allocations as a response to trade liberalization. However, neither of these papers applies the theory to the data. Crozet and Trionfetti (2012) also develop a two-factor model of trade with heterogeneous firms in which the marginal product of individual factors (capital and labor) is heterogeneous, and, therefore, unlike the model of Bernard et al. (2007), the two-factor model translates to Hicks-biased technology. This heterogeneity can generate a within-industry dispersion that is then measured in firm-level data from the AMADEUS database.

9 Problematic access to capital, competition from the informal sector, high tax rates, political instability, the lack of skilled or educated workers, access to electricity, and corruption account for almost 90 percent of all problems reported. The remaining 10 percent of problems include difficulty in registering the firm and obtaining licenses, labor regulations, access to land, customs regulations, macroeconomic instability, tax administration, transportation, economic uncertainty, difficulties in dealing with the legal system, conflict resolution, and crime. 
10 Recent research shows that qualitative self-reported measures are representative of objective conditions of the firms. For example, Hallward-Driemeier and Aterido (2009) show that subjective measures are significantly correlated with objective measures of problematic access to electricity, skills shortage, and other variables.

\section{REFERENCES}

Aguayo-Tellez, Ernesto; Airola, Jim and Juhn, Chinhui. "Did Trade Liberalization Help Women? The Case of Mexico in the 1990s." NBER Working Paper No. 16195, National Bureau of Economic Research, July 2010; www.nber.org/papers/w16195.pdf?new window=1.

Almeida, Heitor and Wolfenzon, Daniel. "The Effect of External Finance on the Equilibrium Allocation of Capital." Journal of Financial Economics, January 2005, 75(1), pp. 133-64.

Bernard, Andrew B.; Jensen, J. Bradford; Redding, Stephen J. and Schott, Peter K. "Firms in International Trade." Journal of Economic Perspectives, Summer 2007, 21(3), pp. 105-30.

Burstein, Ariel and Vogel, Jonathan. "International Trade, Technology, and the Skill Premium." NBER Working Paper No. 16459, National Bureau of Economic Research, 2012.

Crozet, Matthieu and Trionfetti, Federico. "Firm-Level Comparative Advantage." Working paper, Paris School of Economics, November 2012; http://ces.univ-paris1.fr/membre/crozet/FirmComparativeAdv.pdf.

Do, Quy-Toan and Levchenko, Andrei A. “Comparative Advantage, Demand for External Finance, and Financial Development." Journal of Financial Economics, December 2007, 86(3), pp. 796-834.

Do, Quy-Toan; Levchenko, Andrei A. and Raddatz, Claudio. “Engendering Trade." Working Paper No. WPS5777, World Bank, August 2011; www-wds.worldbank.org/external/default/WDSContentServer/IW3P/IB/2011/08/23/ 000158349 20110823155547/Rendered/PDF/WPS5777.pdf.

Do, Quy-Toan; Levchenko, Andrei A. and Raddatz, Claudio. "Comparative Advantage, International Trade, and Fertility." Discussion Paper No. 624, University of Michigan Research Seminar in International Economics, February 15, 2012; www.fordschool.umich.edu/rsie/workingpapers/Papers601-625/r624.pdf.

Galor, Oded and Weil, David N. "The Gender Gap, Fertility, and Growth." American Economic Review, June 1996, 86(3), pp. 374-87.

Gayle, George-Levi; Golan, Limor and Miller, Robert A. "Gender Differences in Executive Compensation and Job Mobility." Journal of Labor Economics, October 2012, 30(4), pp. 829-71.

Hallward-Driemeier, Mary and Aterido, Reyes. “Comparing Apples with...Apples: How to Make (More) Sense of Subjective Rankings of Constraints to Business." Working Paper No. WPS5054, World Bank, September 2009; http://elibrary.worldbank.org/docserver/download/5054.pdf?expires=1354644540\&id=id\&accname=quest\&checks um=15AFDE314489A4B78F5C5CA18E6D3544.

Harrigan, James and Reshef, Ariel. "Skill Biased Heterogeneous Firms, Trade Liberalization, and the Skill Premium." NBER Working Paper No. 17604, National Bureau of Economic Research, November 2011; www.nber.org/papers/w17604.pdf?new_window=1.

Keller, Elisa (2012). “Experience and the Gender Wage Gap across Occupation.” Unpublished manuscript, University of lowa, 2012.

Leonardi, Marco. “Firm Heterogeneity in Capital-Labour Ratios and Wage Inequality." Economic Journal, March 2007, 117(518), pp. 375-98.

Melitz, Marc J. "The Impact on Trade on Intra-Industry Reallocations and Aggregate Industry Productivity." Econometrica, 2003, 71(6), pp. 1695-725.

Oostendorp, Remco H. "Globalization and the Gender Wage Gap." World Bank Economic Review, January 2009, 23(1), pp. 141-61.

Rees, Ray and Riezman, Raymond G. "Globalization, Gender and Growth." Review of Income and Wealth, March 2012, 58(1), pp. 107-17. 


\section{Contessi, de Nicola, Li}

Rendall, Michelle. "Brain Versus Brawn: The Realization of Women's Comparative Advantage." Working Paper No. 306, University of Zurich, September 2010; www.econ.uzh.ch/ipcdp/Papers/ipcdp_wp306.pdf.

Romalis, John. "Factor Proportions and the Structure of Commodity Trade." American Economic Review, 2004, 94(1), pp. 67-97.

Sauré, Philip and Zoabi, Hosny. "Effects of Trade on Female Labor Force Participation." Working Paper No. 2009-12, Swiss National Bank, 2009; www.snb.ch/n/mmr/reference/working_paper 2009_12/source.

World Bank. World Development Report 2012: Gender Equality and Development. Washington, DC: World Bank, 2011. 